\title{
Proposal of Railroad Expansion in the Paraná State Using Geotechnologies
}

\author{
Willyan Ronaldo Becker (Corresponding author)
}

Western Paraná State University - UNIOESTE

Rua Universitária, 1619, Cascavel, Paraná, 85819-170, Brazil

Tel: +55 (45) 3220-7320 E-mail: willyan.becker@ unioeste.br

Elizabeth Giron Cima

Western Paraná State University - UNIOESTE

Rua Universitária, 1619, Cascavel, Paraná, 85819-170, Brazil

Tel: +55 (45) 3220-3228 E-mail: elizabeth.cima@unioeste.br

Elder Elisandro Schemberger

Western Paraná State University - UNIOESTE

Rua Universitária, 1619, Cascavel, Paraná, 85819-170, Brazil

Tel: +55 (45) 3220-7404 E-mail: elder.schemberger@unioeste.br

Erivelto Mercante

Western Paraná State University - UNIOESTE

Rua Universitária, 1619, Cascavel, Paraná, 85819-170, Brazil

Tel: +55 (45) 3220-7366 E-mail: erivelto.mercante@ unioeste.br

Miguel Angel Uribe-Opazo

Western Paraná State University - UNIOESTE

Rua Universitária, 1619, Cascavel, Paraná, 85819-170, Brazil

Tel: +55 (45) 3220-3228 E-mail: miguel.opazo@unioeste.br 
Jerry Adriani Johann

\author{
Western Paraná State University - UNIOESTE \\ Rua Universitária, 1619, Cascavel, Paraná, 85819-170, Brazil \\ Tel: +55 (45) 3220-7320 E-mail: jerry.johann@unioeste.br
}

Eduardo Godoy de Souza

Western Paraná State University - UNIOESTE

Rua Universitária, 1619, Cascavel, Paraná, 85819-170, Brazil

Tel: +55 (45) 3220-7404 E-mail: eduardo.souza@unioeste.br

\author{
Received: Apr. 14, 2020 Accepted: May 6, $2020 \quad$ Published: May 12, 2020 \\ doi:10.5296/jas.v8i2.16843 \\ URL: https://doi.org/10.5296/jas.v8i2.16843
}

\begin{abstract}
Railroad transportation system is considered a viable model in several aspects; however, its implementation is dependent on several decision factors, which include regional production viabilities, specific locations for railroad station construction, land slope, among others. This work aims to indicate the optimal location for new railroad stations and the best interconnection path among them in order to expand the railroad network of the Paraná State (Brazil) to regions that are not contemplated by this type of transportation. The layers used as information plans contemplated the geographic location of the regions with the highest representativeness in the agroindustrial production, associated with the demands and transportation of production and topographic relief. Was defined 1,390.802 km of new railroads, mainly in the Western and Southern Center regions of Paraná. This implantation generates a very significant importance for the municipalities since it increases the demand of revenues and generation of new currencies.
\end{abstract}

Keywords: geographic information systems, railroad networks, transportation of crops

\title{
1. Introduction
}

Transportation Systems are considered routine and necessary activities in the world. However, they are considered as complex and the spatial knowledge depends on the interaction between direct and secondary variables. With the globalization of markets and the internationalization of the economy, these systems became integrated into a necessary part of the logistics system that involves production, distribution and consumption.

Cargo transportation systems involve demographic and relief data, associated with the 
characterization of the movement and displacement of goods and services, with spatial connections linked to social, economic, and environmental issues (ARANTES; FERREIRA, 2011). One of the attributes of transportation modes is the integration between different regions and their economic relations, promoting the transportation of production.

The Brazilian railroad system is the largest in Latin America in terms of cargo transported, reaching 162.2 billion tku (tonnes per useful kilometer) (ANTT, 2019a). Although the Western region of Paraná is considered promising regarding its contribution to agroindustrial production in the state and in Brazil, it does not have sufficient infrastructure for the transportation and storage of grains. The Paraná state is characterized as the third largest producer of soybean and the second largest producer of maize in Brazil, considering the $1^{\text {st }}$ and $2^{\text {nd }}$ growing seasons. In the 2018/2019 crop year, 234.4 million tonnes of grain were produced $^{1}$ in Brazil, of which 36.8 million tonnes, or $15.7 \%$, were the responsibility of Paraná (CONAB, 2019).

The rail terminals are responsible for long-distance and large-scale transportation of cargo, thus reducing losses and costs, since they carry large volumes with low fuel consumption (RECH; MORAIS, CASAROTTO; BINOTTO 2017). Railroad transportation is considered the safest in the world, as the incidences of robberies, accidents, and thefts are lower in relation to the road transportation (ANTT, 2019a). POMPERMAYER (2018) and IPEA (2010) estimates that the tonne transported costs $\mathrm{R} \$ 65.00$ using the highway and $\mathrm{R} \$ 20.00$ using the railroad per $1,000 \mathrm{~km}$. Correa and Ramos (2010) claim that, behind only the waterway modal, the railroad modal is the most economical and efficient means of transport. Although it presents low costs, the waterway modal is not always practical, since it requires navigable rivers. Thus, the railroad modal tends to serve cargo transport more widely.

Currently, the railroad modal is considered as insufficient to supply the demand in the periods of crop harvests, being necessary the construction of new railroad channels in the Paraná State.

In this sense, there is a need for alternative routes between regions that may actually facilitate the transportation of production. However, the location of these routes is a determining factor since they must be related to the production by municipality, so it is important to consider the collection rate by municipality, since this collection rate will be associated with productive capacities and transportation (SEFAZ, 2019).

Caixeta-Filho (2014) also affirm that for the implantation of a railroad route, the geography of the region associated with the demography of the relief must be considered, without considering the investments. The monitoring of what happens in the agricultural sector, from the receipt of inputs and seeds, becomes a decisive factor for the efficiency of agricultural operations and reinforces the importance of studies that analyze the costs of transportation, storage, distribution, and maintenance of the fleet.

The multicriteria analysis aims at structuring and combining different analyses for

${ }^{1}$ Grains: herbaceous cotton (cottonseed), rice, beans, castor beans, corn, soybean, oats, rye, barley, sunflower, sorghum, wheat, and triticale. 


\section{NI Macrothink}

decision-making, evaluating all the possible effects of the different agents involved (MARTINS et al., 2014). Several studies are used as references for this work, being they: simulation of the route of a gas pipeline in the state of São Paulo, Brazil (MERCANTE; ANTUNES, 2010), and evaluation the use of GIS and multicriteria analysis in the definition of high-speed train routes that incorporates the Trans-European Transport Network (TEN-T) (DE LUCA; DELL'ACQUA; LAMBERTI, 2012). As result, MERCANTE; ANTUNES (2010) defined the best route of the gas pipeline with less environmental impact and minimal financial resources and DE LUCA; DELL'ACQUA; LAMBERTI (2012) presented three alternative routes for high-speed train routes, considering the conservative, compromise and innovative points of view. The technique gains relevance by allowing a periodic monitoring with rich detail of production and spatial visualization of the areas with the greatest tendency of agricultural production.

The objective of this work is to propose a scenario for the implantation of new railroad stations, as well as routes for their interconnection, following economic and technical criteria, with the use of geotechnologies (GIS and information plans), in order to interconnect the origin and destiny of the cargo and aiming to revert the great losses of production by the depreciation of the road network and road fleets.

\section{Material and Methods}

\section{Study Area}

The study area comprises the Paraná state, southern Brazil, located between the parallels $22^{\circ} 29^{\prime} \mathrm{S}$ and $26^{\circ} 43^{\prime} \mathrm{S}$ and the meridians $48^{\circ} 20^{\prime} \mathrm{W}$ and $54^{\circ} 38^{\prime} \mathrm{W}$, with 399 municipalities (Figure 1). The choice of the region was due to its agricultural production expressiveness, since it is the second largest producer of soybean and the largest producer of maize in Brazil (CONAB, 2016, 2018; IAPAR, 2015; IBGE, 2020; SEFAZ, 2019).

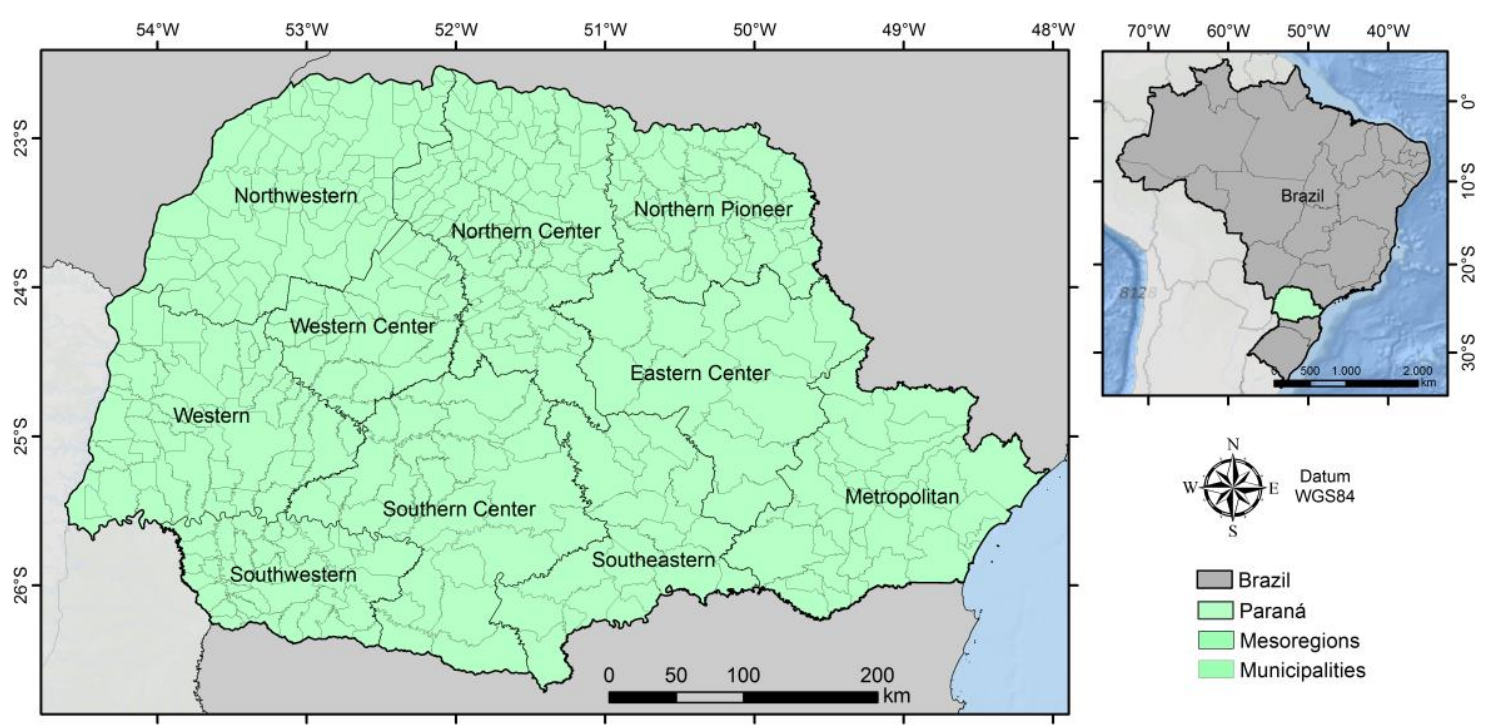

Figure 1. Location map of the state of Paraná 


\section{1) Macrothink}

\section{Materials}

The methodology of the work was carried out using the software ARCGIS (version 10.0). The input information plans used were: SEFAZ ICMS tax (2019), location of the stations of the current railroad network and highways, obtained from ANTT (National Agency of Land Transport) and DNIT (National Department of Transport Infrastructure), maps of the slope of the ITCG (Cartography and Geoscience Land Institute), and images of the EVI (Enhanced Vegetation Index) of the Modis sensor (Terra and Aqua satellites - Earth Explorer). To facilitate the understanding of all operations performed in this work, the following subsections detail the steps with the flowchart in the figures.

\section{Spatial analysis with the information plans of Agricultural Production and municipal ICMS}

For the operations in the GIS with the information plans, a pre-processing was necessary. Initially, the production of the crop years (2008/2009 to 2012/2013) for soybean was considered, according to SEAB (State Department for Agriculture and Food Supply) (SEAB, 2019). A ranking was carried out for this production by municipality, from the highest to the lowest, and was subsequently reclassified them into five classes, at $20 \%$ intervals, to differentiate municipalities with higher and lower production. This procedure was also applied to the information plan of the ICMS (State Value-Added Tax) contribution by municipality, obtained from (SEFAZ, 2019), after the first exclusion, in which the 240 municipalities with the highest ICMS (60\% of the total) of Paraná were considered for analysis. With these two information plans, it could associate agricultural production with ICMS contribution using a multiplication operation (

Figure 2. Flowchart of operations and production map multiplied by the ICMS contribution map by municipality, resulting in three main classes: green (first), yellow (second), and orange (third)

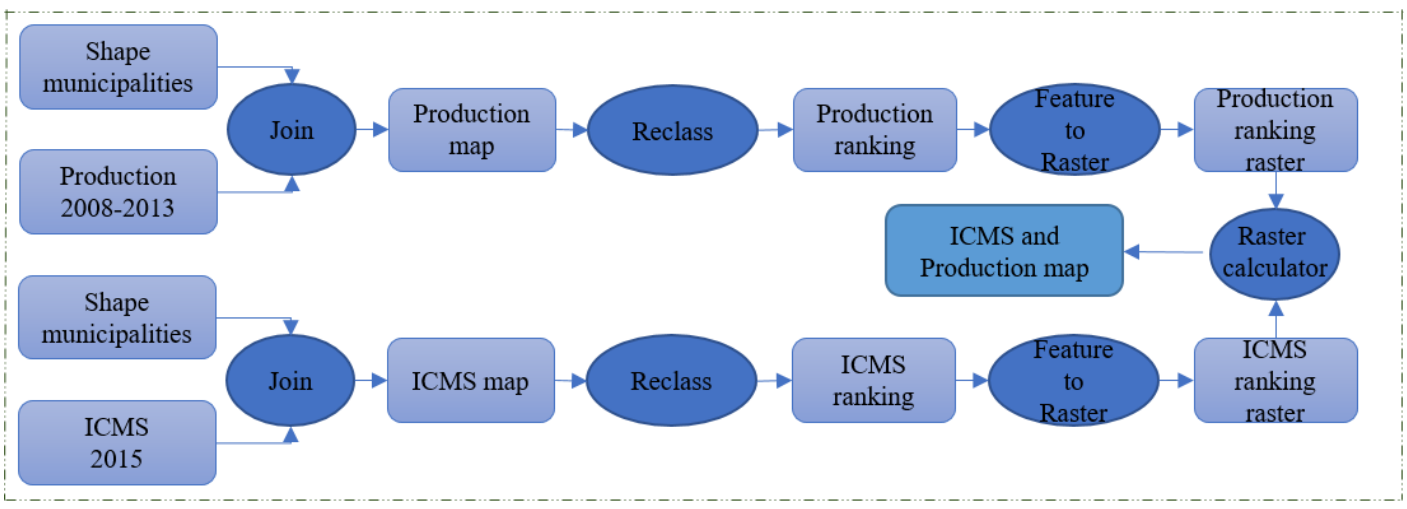




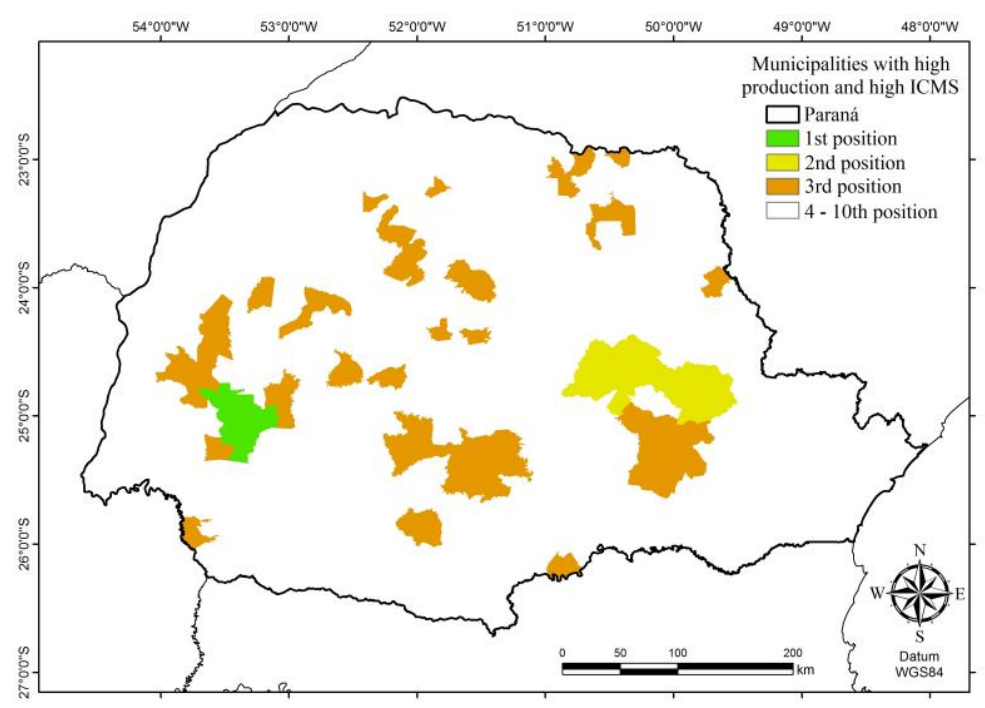

Figure 2. Flowchart of operations and production map multiplied by the ICMS contribution map by municipality, resulting in three main classes: green (first), yellow (second), and orange (third)

The resulting map shows the municipalities that have high ICMS contribution, while agricultural production has remained high in the 6 years. This resulting map groups the data into three classes, so that the municipalities with the highest productions and biggest ICMS collections were grouped from the largest to the smallest, following the colors of green (first), yellow (second), and orange (third), respectively. It should be noted that the blank areas, with captions 4 to 10, are the other municipalities with low ICMS contribution and/or low production, and they were therefore excluded by the operation performed as described above.

\section{Spatial analysis with the city information plan}

One of the information plans obtained from the primary source were the satellite images collected in order to use the vegetation index as a parameter to define the outlines of the cities. As this index is used to evaluate the spectral response of plans (HUETE et al., 2002), urban areas tend to be dark, with low reflectance. A maximum value image of vegetation index was performed with a time series of 32 images of the EVI of the MODIS sensor (TERRA satellite) throughout 2014 to define the sites that were cities (dark areas). In doing so, it can be contemplated an entire year of agricultural production for Paraná. Based on these images, was carried out the outline of the urban areas of the municipalities ranked by production and ICMS (

Figure 2. Flowchart of operations and production map multiplied by the ICMS contribution map by municipality, resulting in three main classes: green (first), yellow (second), and orange (third)

), given that they are the focus of the proposal for the implementation of new railroad stations. This operation was performed manually, generating a new Shapefile. With the outlines made, 


\section{Ml Macrothink}

was used the distance operator BUFFER to create the minimum radius of 5,000 meters, and a maximum radius of 15,000 meters around the cities. The main premises considered for the definition of these radius values around the urban areas were the possibility of growing of the urban area and, at the same time, they should not being too distant, so that the implantation of industrial parks or similar near the new railroad stations can be logistically possible.

In order to obtain the region of interest (between 5,000 and 15,000 meters of the outlines of urban areas), the ERASE operation was carried out. The area suitable for the construction of railroad stations, after carrying out these operations, is highlighted in Figure 3.
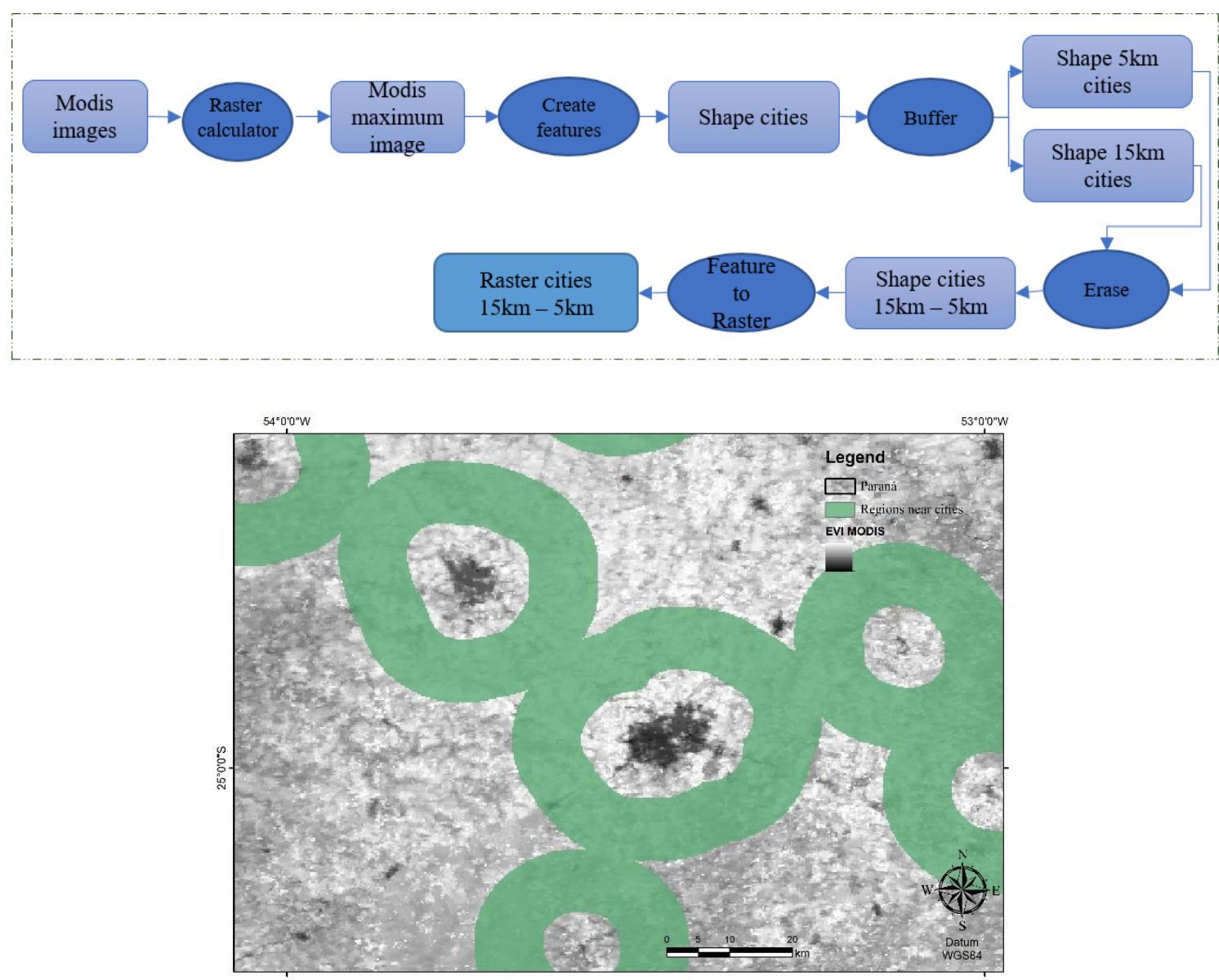

Figure 3. Areas suitable for the implementation of railroad stations highlighted in green, comprising 5,000 to 15,000 meters around the cities

\section{Spatial analysis with the highway information plan}

The integration of the new proposed railroad stations to existing highways are important for the transportation logistics feasibility involved, because the closer to the roads such stations are, the more attractive this transportation mode is for agricultural production. In order to carry out the operations related to the highway information plan of Paraná, was used the highway vector provided by DNIT (2019). As mentioned, the proposed railroad stations should be as close to the highways as possible. In this way, a maximum distance of 3,000 $\mathrm{m}$ was defined for each side of the highways. 


\section{Mll Macrothink}

With the information plans generated and transformed from vector to raster (image), could associate this information with those obtained in subsection 2.2 (minimum and maximum distance of the cities of interest) and 2.1 (cities with high ICMS contribution and high production at the same time). By grouping all this information into a single new information plan, there is the map of Figure 4.
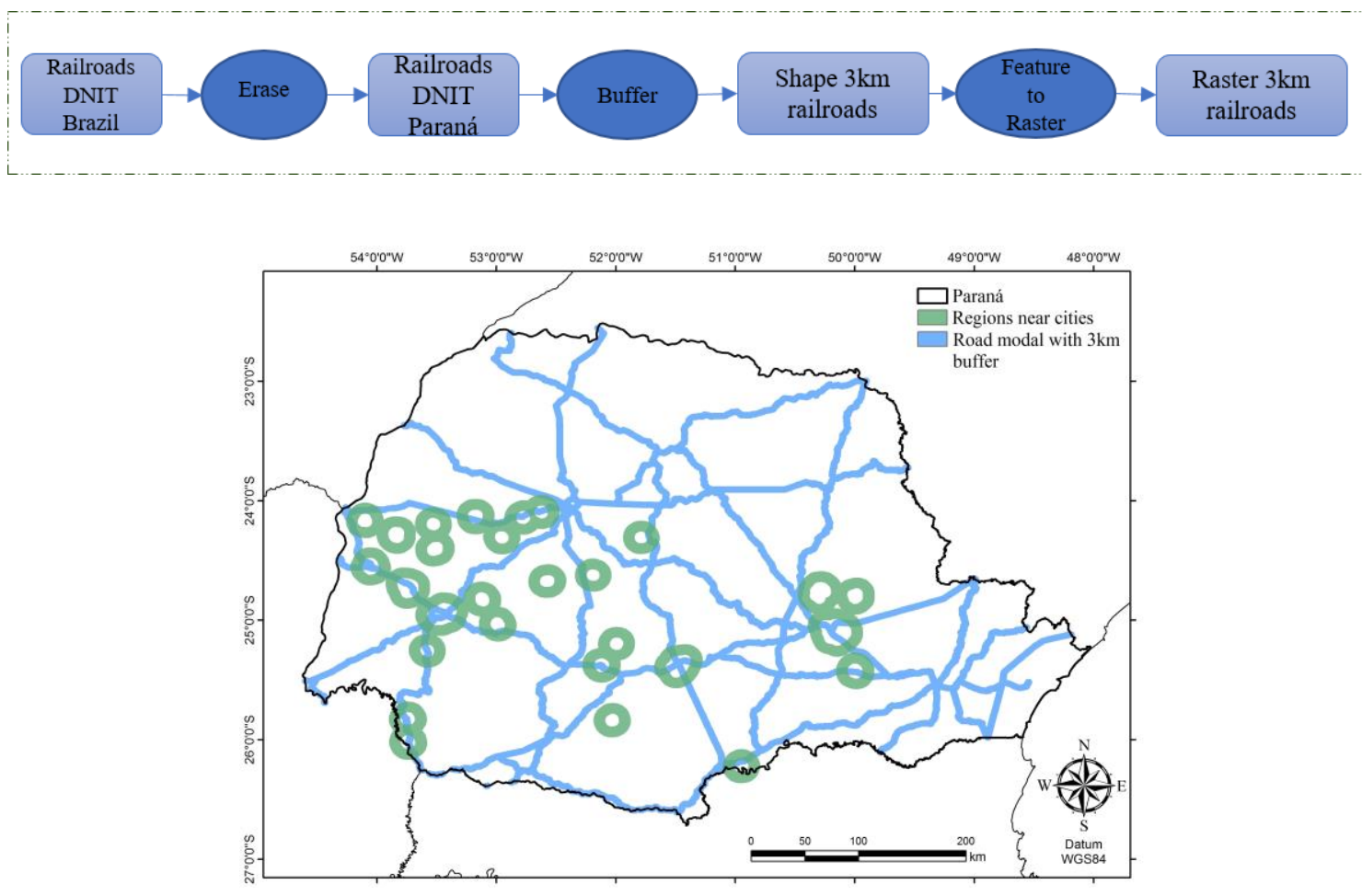

Figure 4. Overlapping of the maps of the Paraná road modal (light green) with the map of regions near cities with distances between 5,000 $\mathrm{m}$ and 15,000 $\mathrm{m}$ (dark green)

As the interest is in finding the most appropriate places for the implantation of new railroad stations, by multiplying the possibilities of proximity with highways and with cities, it was obtained the regions of the map that comprise the buffer of highways, as well as the buffer of cities. Figure 5(a) shows the result on the map for Paraná, and in Figure 5(b) the Western region of Paraná is highlighted, making the intersection between the information planes used clearer (lighter color). 


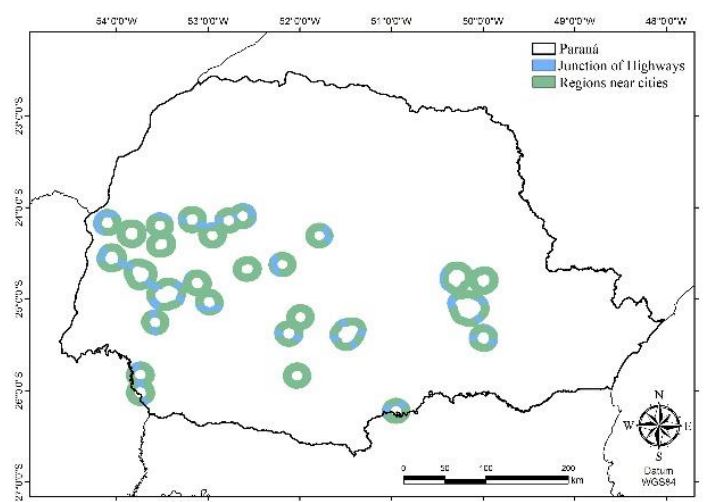

(a)

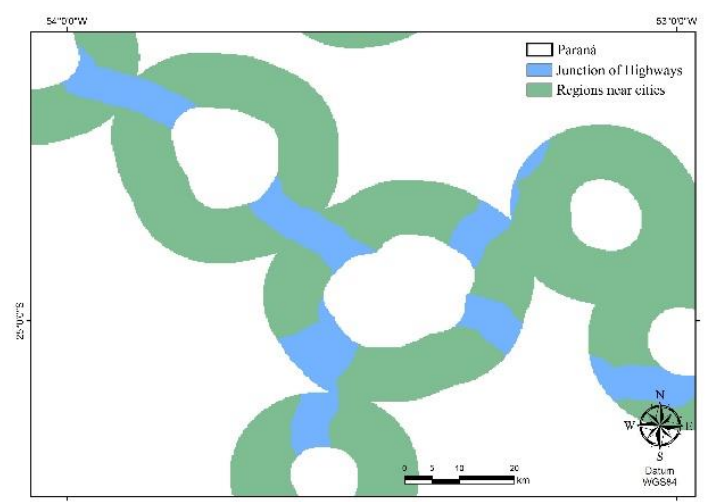

(b)

Figure 5. Junction of Highways with Cities (buffers) (a), and a highlight for the western region of Paraná (b)

\section{Spatial analysis with the terrain slope information plan}

In railroad transportation, the slope of the terrain has a direct influence on the proposed construction of railroads, given the inherent characteristics of this activity. In this way, was used as a parameter the slope obtained from ITCG (2019) of a maximum of $10 \%$ to direct the paths and locations for the construction of the new stations. Thus, the slope values in the state of Paraná are presented, separated into four classes (Figure 6a), and separated into two classes - the one of interest, up to 10\%, and the remainder, over 10\% (Figure 6b). 


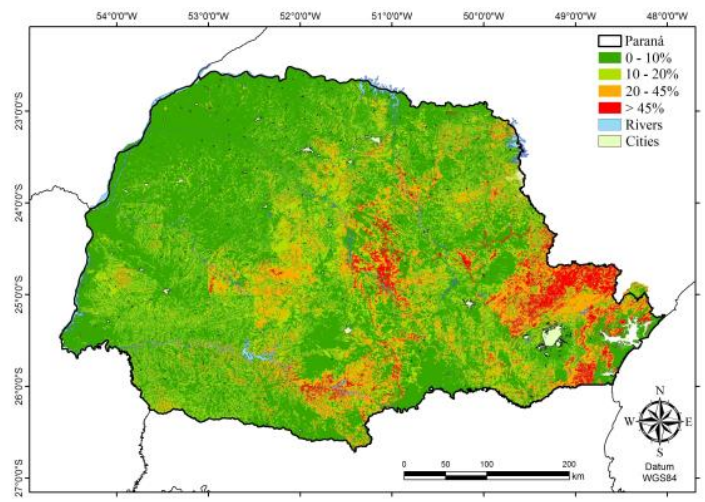

(a)

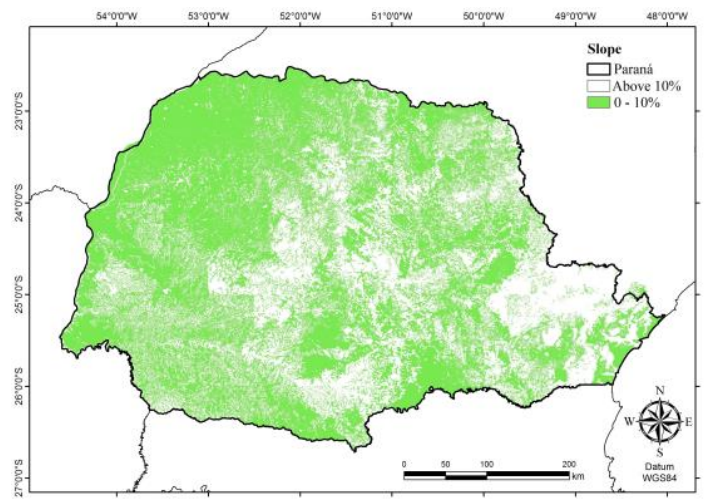

(b)

Figure 6. Map of the Slope of the State of Paraná with 4 classes (a), and Map of the Slope of the State of Paraná with 2 classes: between 0 and $10 \%$ and above $10 \%$ of slope (b)

By associating the slope of the class below $10 \%$ with the regions of interest already obtained, according to subsection 2.3, was achieved the points of interest for the implementation of the new railroad stations, as shown in Figure 7.
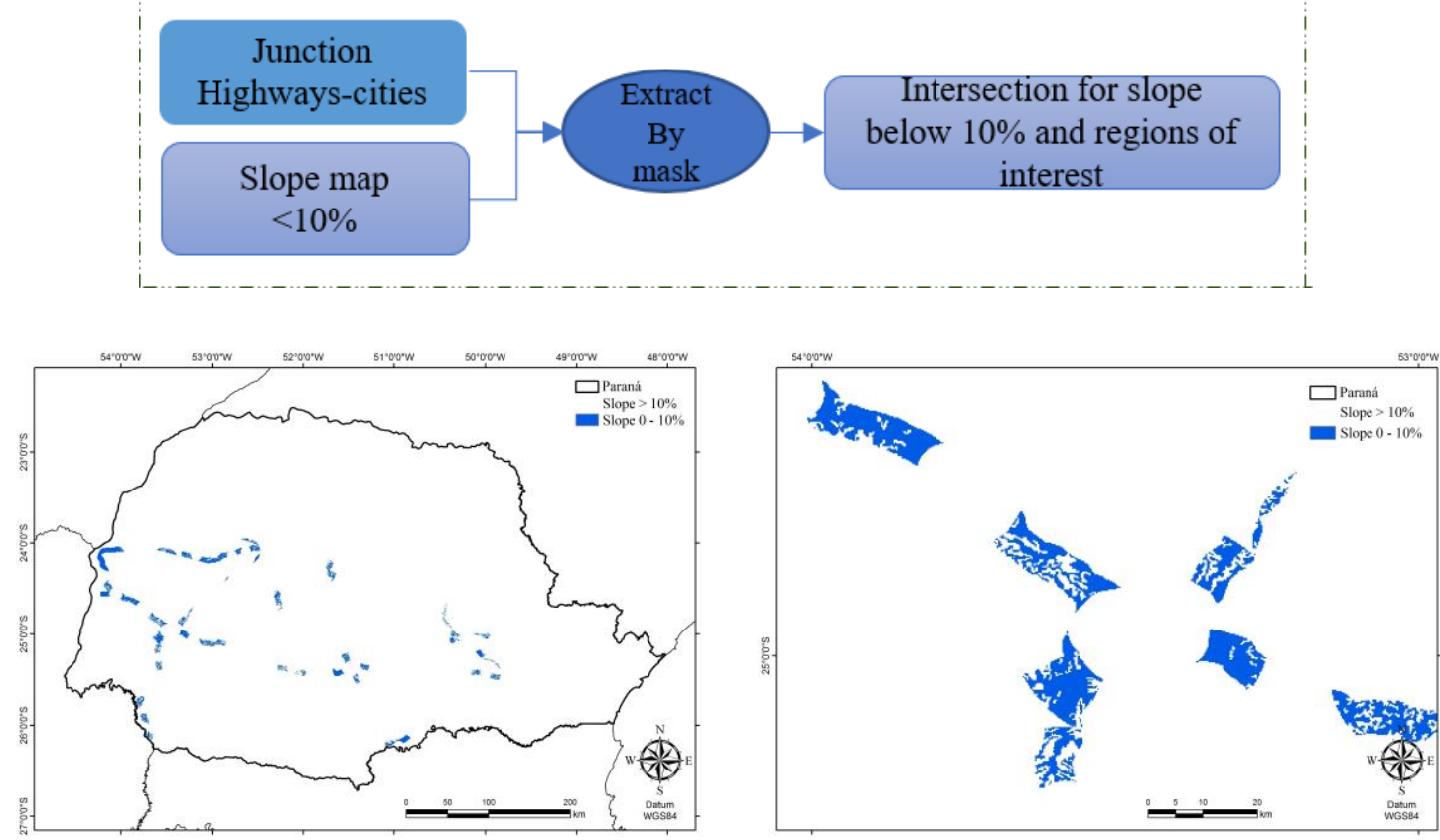

Figure 7. Intersection for slope below $10 \%$ and regions of interest for the implantation of new railroad stations (a), and highlight for the region of Cascavel and Toledo (Western Paraná)

(b) 


\section{Macrothink}

\section{Spatial analysis with the information plan of existing railroad stations}

When proposing new railroad stations, it is necessary to associate the information plan of the existing stations and railroad network, in order to avoid their overlapping, since the objective is to propose the implantation in places that do not yet contemplate them. Using this criterion, was obtained the information plan with the existing railroad stations and their interconnection (ANTT, 2019b), as shown in Figure 8.

Similar to the operations proposed in this work, a buffer of 30,000 $\mathrm{m}$ of these existing stations was also generated in order not to overlap or propose new stations in spaces very close to those that already exist.

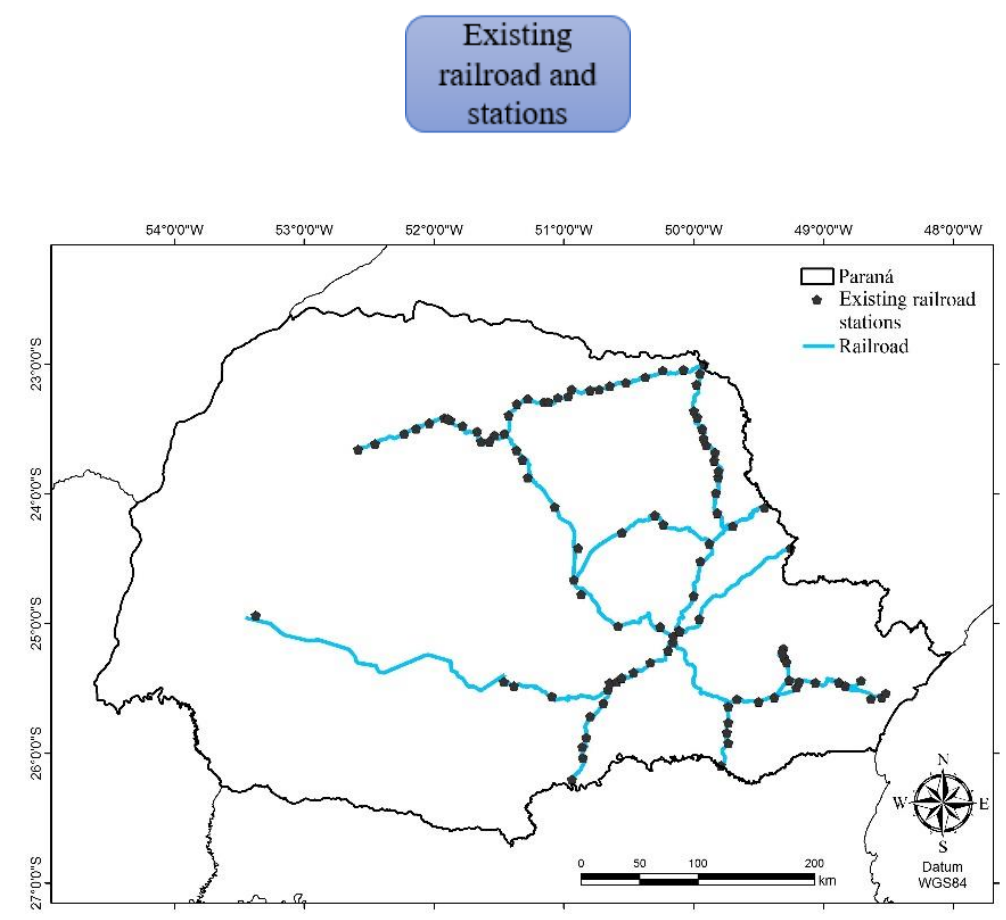

Figure 8. Existing Railroad Stations and the networks that interconnect these railroad stations

\section{Definition of new railroad stations}

Based on the images generated by the association of information and buffers, the points for new stations were manually chosen, using the sum of the criteria and previous knowledge, in order to contemplate the points of the regions of interest, with appropriate slope and no railroad stations. Figure 9 illustrates the green points selected for these new stations. 


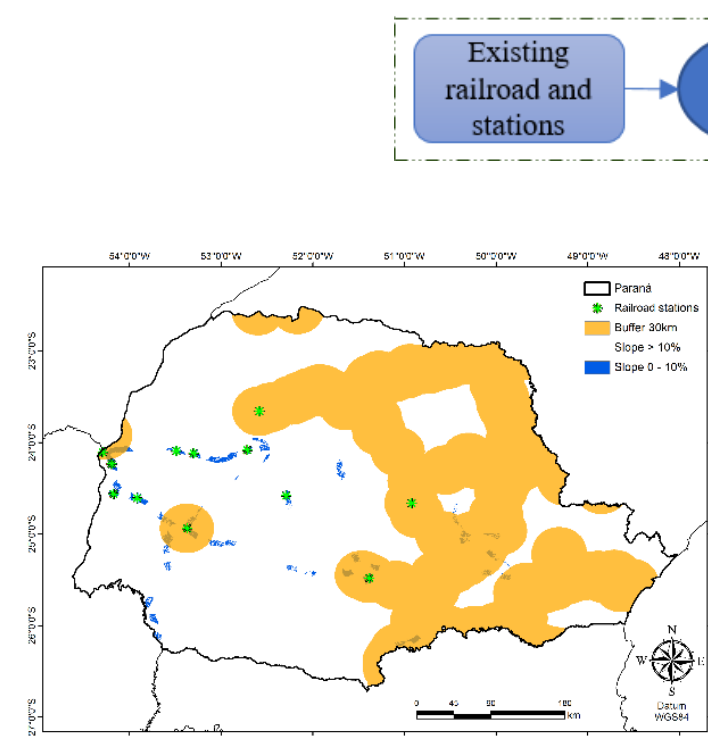

(a)

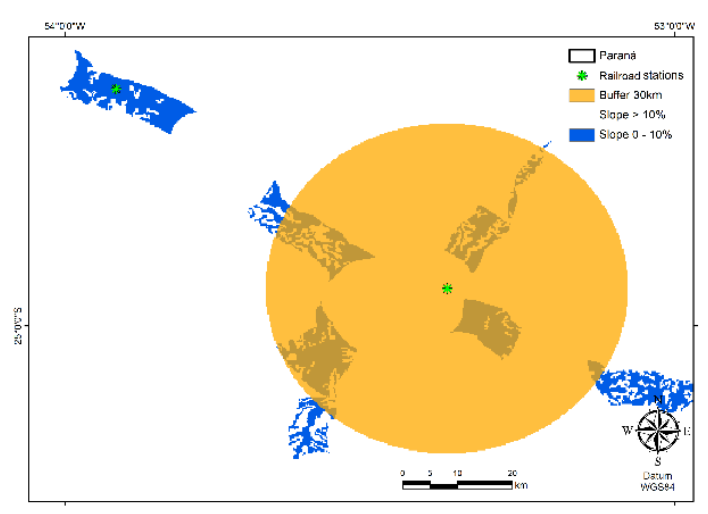

(b)

Figure 9. Location of the new railroad stations (a), and an approximation of the western region of Paraná (b)

\section{Definition of new railroads connecting the proposed road stations}

After defining the points for the new railroad stations, we had to carry out their interconnection in the railroad network. For this purpose, was used the slope classes defined in Figure 7 (a), defining weights 1, 50, 100, and 10,000, in order to direct the network to the lowest possible slope, so that the railroad network would not invade the $5,000 \mathrm{~m}$ of proximity to urban areas. Thus, a friction image of the slope indices/classes was generated with the previously generated buffer. Figure 10 shows the image resulting from this operation. 

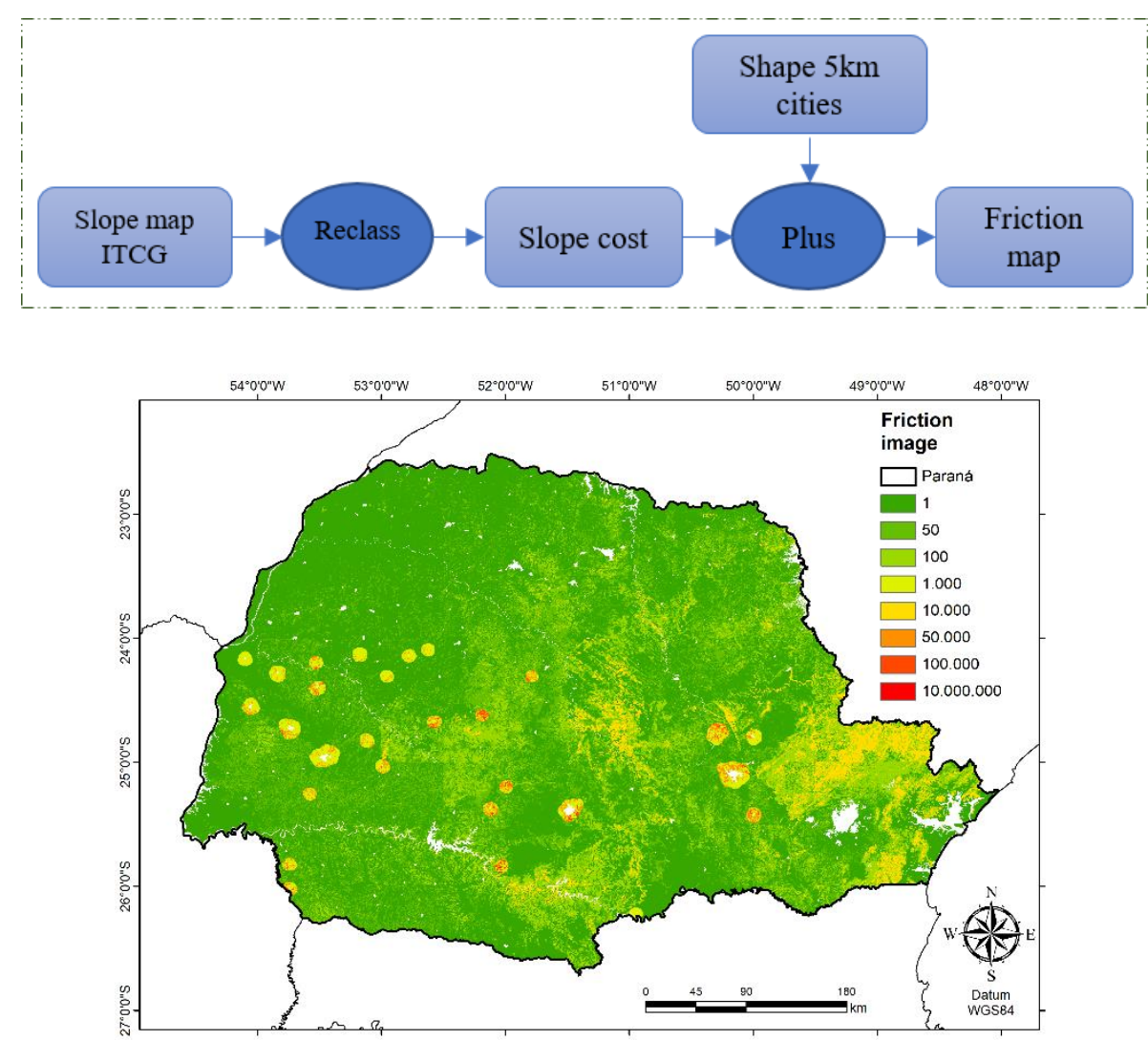

Figure 10 . Friction image of the proximity buffer of cities $(5,000 \mathrm{~m})$ with respective slope weights

With the friction image and the station points, was needed to carry out the cost-distance operation for each city with the closest city, whose define the weight of the possible interconnection route, based on the previous spatial analysis. When performing the operation between each pair of stations, then have the generated railroad network that interconnects all the proposed new stations.

\section{Results and Discussions}

In order to propose new railroad stations as well as their interconnection, this work presented strategic management planning and execution based on current and consistent information plans. Although the state of Paraná has 399 municipalities, was only considered for mapping those with characteristics of large soybean producers, with the highest tax (ICMS) collection rates. The ICMS as a criterion is based on the fact that agribusiness is a protagonist of the Brazilian economy, generating income and employment, reflecting directly and indirectly on the municipal wealth (FERREIRA, 2018).

The central strategy for the points to receive new stations as well as the interconnection of these stations was based on minimum and maximum distance criteria of the municipalities of the region of interest. Efficiency in the creation of route masks for variables such as terrain slope and urban areas was also considered in order not to compromise machinability and to optimize the cost/benefit ratio of the railroad system. 


\section{Macrothink}

Thus, Figure 11 illustrates in the green points the proposed new railroad stations, and in red the interconnection network of these stations considering all associated variables. Was defined eight new locations for the creation of railroad stations and four interconnection sites with existing stations. Was defined 1,390.802 $\mathrm{km}$ of new railroads, mainly in the Western and Southern Center of Paraná. This implantation could be of very significant importance for the municipalities since it could increase the demand of revenues and generation of new currencies.
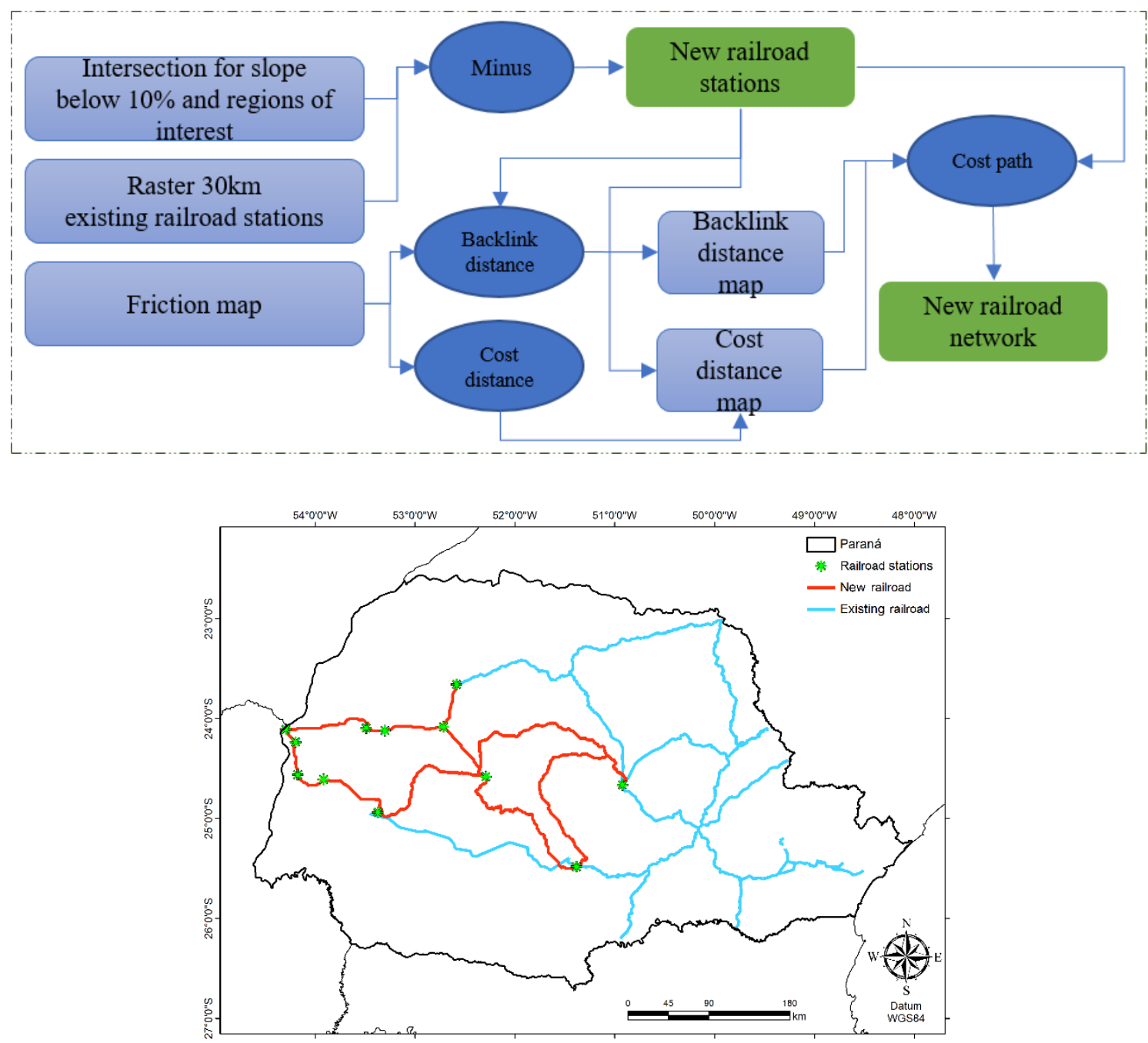

Figure 11. New proposed railroad network (in red) and its integration with the existing railroad network (in blue).

The cities that benefited the most from the new railroad network suggested here are Brasilândia do Sul, Farol, Guaíra, Marechal Candido Rondon, Mariluz, Roncador, and Toledo, because they have railroad stations built within the perimeter of the municipality. The cities in which the railroad will pass by are also benefited, which are: Alto Piquiri, Araruna, Ariranha do Ivaí, Boa Ventura de São Roque, Braganey, Cafezal do Sul, Campina da Lagoa, Campina do Simão, Corbélia, Francisco Alves, Goioerê, Iporã, Janiópolis, Juranda, Luiziana, Mamborê, Manoel Ribas, Mato Rico, Mercedes, Moreira Sales, Nova Cantú, Palmital, Pitanga, Rio 


\section{$\triangle 1$ Macrothink}

Branco do Ivaí, Rosário do Ivaí, Santa Maria do Oeste, Terra Roxa, Turvo, and Ubiratã. Finally, cities that already have a railroad station will benefit from the expansion of the movement of cargo at their terminals, being they: Cascavel, Cianorte, Guarapuava, and Reserva.

Another important factor in this case is the high agricultural production in the Western region, thus favoring the most dynamic transportation of grain production in the period of harvests. Aguilar; Shikida; Lobo (2018) report the need to prospect for alternative routes for the flow of production from western Paraná. The authors comment that the current model of cargo transportation in the region created bottlenecks for the flow of production up to the Paranaguá port, the only viable road route being BR-277, which is not completely duplicated and has high toll fees (AGUILAR; SHIKIDA; LOBO, 2018). Therefore, the adoption and implementation of a larger railroad network favors, in this sense, economic growth and the development of municipalities.

The proposed network (in red), Figure 11, was interconnected with the railroad network already existing in the state of Paraná (in blue) in order to optimize the transportation of agricultural production using existing routes.

By overlapping the proposed railroad network with the mapping of soybean production in the Paraná state for the crop year of 2014/2015 (GRZEGOZEWSKI et al., 2016), we can see that transportation could be optimized, as can see the outline of a region of great agricultural production that is not yet reached by this type of transportation, which can also be linked with the existing rail network. Figure 12 illustrates this overlap and ratifies such statements.
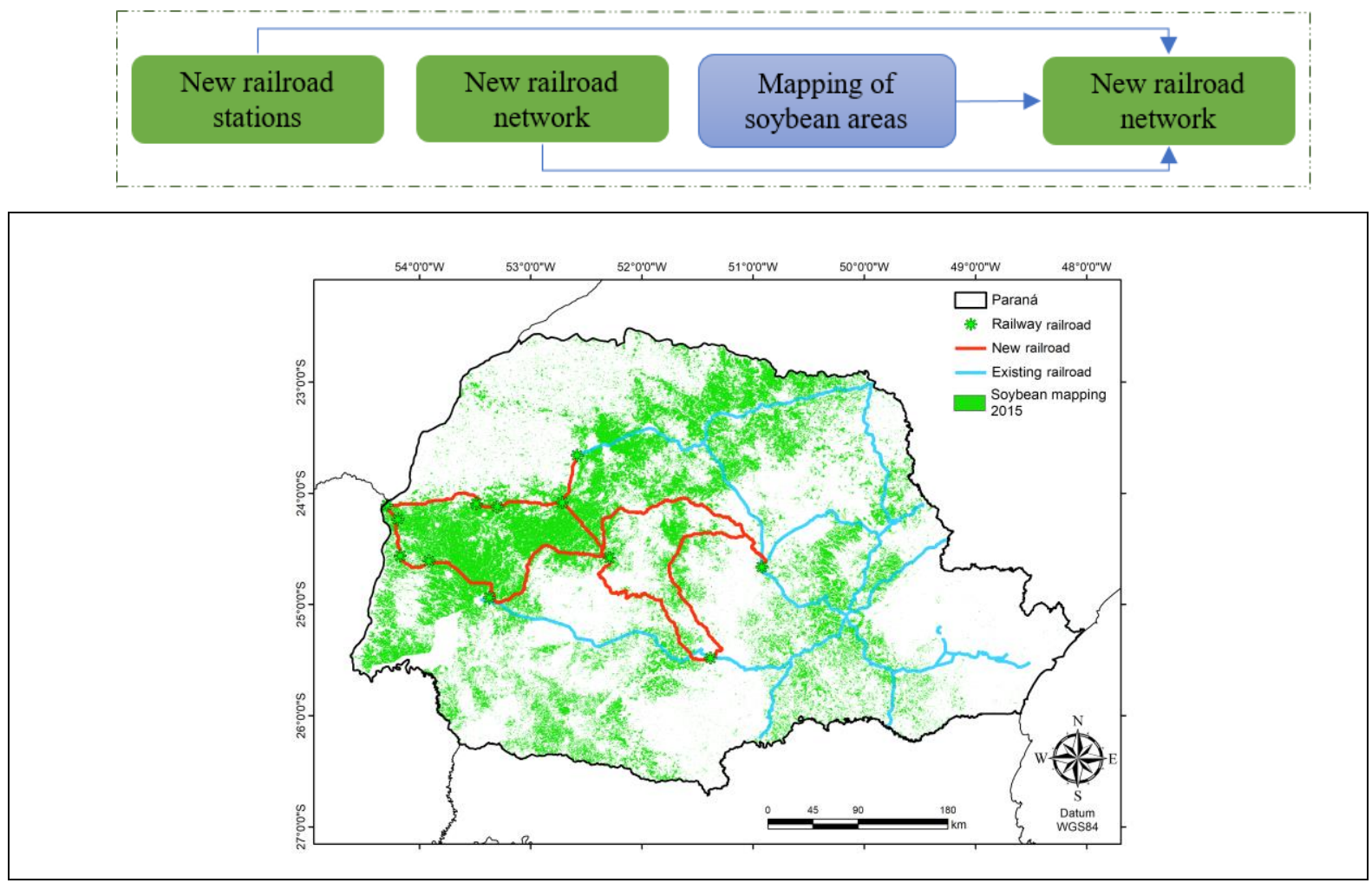

Figure 12. Railroad network (existing and proposed) overlapping the soybean mapping in 2014/2015 in the state of Paraná 


\section{Conclusions}

The application of GIS in geoprocessing shows criteria of planning, management, and techniques that allow their association in common information plans, something that would be impossible without the use of software that perform these operations.

The proposal of new railroad stations, as well as their interconnection with the existing railroad network, is an economically viable and necessary need for the Paraná state, Brazil, and this work pointed out, based on technical and strategic criteria, how this decision could be conducted.

Thus, the questions proposed in this study were answered, as there is no proper railroad network to meet the demand of agricultural transportation, especially in the Western region of Paraná. The idea of new railroad routes considering the agricultural production associated with the ICMS tax showed that regions with higher production earn more and consequently need a more dynamic and versatile transportation, and the proposal to implement the new railroad is innovative and necessary; therefore, this work proposed 1,390,802 $\mathrm{km}$ of new railroads to incorporate the existing railroad network, as well as eight sites for the creation of new railroad stations.

The authors suggest as future studies the execution of the operations listed in the flowcharts, but without ruling out the existing stations/railroads, in order to compare whether what is constructed reflects only technical interests (based on the approach proposed here) or was constructed by other indicatives. It is also interesting to carry out the operations of this work with other information plans such as different crops and at different times to consider other demands for the transportation of products such as live animals, cold meats, among others.

\section{Acknowledgement}

The authors thank the financial support of the Coordination for the Improvement of Higher Education Personnel (CAPES), Financing Code 001, the National Council for Scientific and Technological Development $(\mathrm{CNPq})$ - Brazil, and the Western Paraná State University-Brazil.

\section{References}

Aguilar, C. J. P., Shikida, P. F. A., \& Lobo, D. da S. (2018). Logística de exportação de grãos do Oeste do Paraná: perspectivas de potencialidades. Planejamento e Políticas Públicas, 51, 65-100.

ANTT, Agência Nacional de Transportes Terrestres (2015a). Cargas. [Online] Available: http://www.antt.gov.br/cargas/index.html (December 1, 2015)

ANTT, Agência Nacional de Transportes Terrestres (2015b). Infraestrutura Ferroviária. [Online] Available: http://portal.antt.gov.br/index.php/content/view/4751/Ferroviaria.html (November 15, 2015)

Arantes, T. G. F., \& Ferreira, W. R (2011). The geoprocessing in the elaboration of thematicmaps of freight transportation: The "Triângulo Mineiro e Alto do Paranaíba/MG" 
Mesoregion. Geografia Ensino \& Pesquisa, 15(2), 19-40. https://doi.org/10.5902/223649947361

Caixeta-Filho, J., \& Martins, R (2014). Gestão logística do transporte de cargas. São Paulo: Atlas.

CONAB, Companhia Nacional de Abastecimento (2016). Acompanhamento da Safra Brasileira - Grãos - Safra 2015/16 - 7-Levantamento Brasília.

CONAB, Companhia Nacional de Abastecimento (2018). Acompanhamento da Safra Brasileira - Grãos - Safra 2017/18 - 10- Levantamento Brasília.

CONAB, Companhia Nacional de Abastecimento (2019). Acompanhamento da Safra Brasileira - Grãos - Safra 2018/2019 - 12- Levantamento Brasília.

DE Luca, M., Dell'Acqua, G., \& Lamberti, R (2012). High-Speed Rail Track Design Using GIS And Multi-Criteria Analysis. Procedia - Social and Behavioral Sciences, 54, 608-617. https://doi.org/10.1016/j.sbspro.2012.09.778

DNIT, Departamento Nacional de Infraestrutura de Transportes (2015). Mapas Multimodais. [Online] Available: http://www.dnit.gov.br/mapas-multimodais/shapefiles (November 15, 2015)

Ferreira, R. M. (2018). Transferência intergovernamental do cota-parte do ICMS aos municípios do estado do Paraná: análise dos critérios de produção agropecuária e fator ambiental. (Dissertação de Mestrado). Programa de Pós-Graduação em Contabilidade. Universidade Estadual do Oeste do Paraná, Cascavel/PR.

Grzegozewski, D. M., Johann, J. A., Uribe-Opazo, M. A., Mercante, E., \& Coutinho, A. C. (2016). Mapping soya bean and corn crops in the State of Paraná, Brazil, using EVI images from the MODIS sensor. International Journal of Remote Sensing, 37(6), 1257-1275. https://doi.org/10.1080/01431161.2016.1148285

Huete, A., Didan, K., Miura, T., Rodriguez, E. P., \& Gao, X. (2002). Overview of the radiometric and biophysical performance of the MODIS vegetation indices. Remote Sensing of Environment, 83(1-2), 195-213. https://doi.org/10.1016/S0034-4257(02)00096-2

IAPAR, Instituto Agronômico do Paraná (2015). Monitoramento Agroclimático. [Online] Available: http://www.iapar.br/modules/conteudo/conteudo.php?conteudo=667 (November $15,2015)$

IBGE, Instituto Brasileiro de Geografia e Estatística (2017). Banco de dados agregados. [Online] Available: http://www.sidra.ibge.gov.br. (September 18, 2017)

IPEA, Instituto de Pesquisa Econômica Aplicada. (2010). Infraestrutura econômica no Brasil: diagnósticos e perspectivas para 2025/Instituto de Pesquisa Econômica Aplicada. - Brasília: Ipea, 586 p.

ITCG, Instituto de Terras Cartografia e Geociências (2015). Dados e informações geoespaciais temáticos. [Online] Available: http://www.itcg.pr.gov.br/modules/faq/ 
category.php? categoryid=9\# (November 15, 2015)

Martins, F. C. M., Andrade, L. C. R., Calijuri, M. A., Barros, K. O., \& Barreto, E. M. (2014). Multicriteria analysis and geoprocessing for conservation of unpaved roads. Revista de Ciências Agrárias, 37(2), 162-170.

Mercante, E., \& Antunes, J. F. G. (2010). Simulação de trajetos de um gasoduto integrando dados de sensoriamento remoto e sistemas de informação geográfica. Acta Scientiarum Technology, 32(2), 171-178. https://doi.org/10.4025/actascitechnol.v32i2.1133

Pompermayer, F. M. (2018). Ferrovias no Brasil: Breve histórico, desafios e perspectivas. Instituto de Pesquisa Econômica Aplicada (IPEA). Brasília. Available: http://legis.senado.leg.br/sdleg-getter/documento/download/73aad52c-143a-4c04-a228-76072 e4abcd3

Rech, L. R., Morais, M., Casarotto, E. L., \& Binotto, E. (2017). Análise situacional das rodovias federais para o escoamento da produção do agronegócio em Mato Grosso do Sul e Mato Grosso, Revista Técnico-Científica, 22(37), 37-51. https://doi.org/10.30945/ccei.v22i37.152

SEAB, Secretaria de Estado da Agricultura e do Abastecimento (2017). Divisão de Estatísticas Básicas. [Online] Available: http://www.agricultura.pr.gov.br/modules/conteudo/ conteudo.php?conteudo=75 (September 18, 2017)

SEFAZ, Secretaria da Fazenda Estado do Paraná (2019). Imposto. [Online] Available: http://www.fazenda.pr.gov.br/modules/conteudo/conteudo.php?conteudo=466 (October 1, 2019)

\section{Copyright Disclaimer}

Copyright for this article is retained by the author(s), with first publication rights granted to the journal.

This is an open-access article distributed under the terms and conditions of the Creative Commons Attribution license (http://creativecommons.org/licenses/by/4.0/). 